\title{
Synthesis of PLA/SBA-15 Composite Scaffolds for Bone Tissue Engineering
}

\author{
Osmar Alejandro Chanes-Cuevas ${ }^{a}$, Ulises Arellano-Sánchez ${ }^{b}$ (D), Carlos Andrés Álvarez-Gayosso ${ }^{c}$, \\ Fernando Suaste-Olmos ${ }^{d}$,Eduardo Villarreal-Ramírez ${ }^{a}$, Octavio Álvarez-Fregoso ${ }^{e}$,Manuel García- \\ Hipólito $^{e}$, Patricia González-Alva ${ }^{e}$ (D), Marco A. Álvarez-Pérez ${ }^{a *}$ (D)
}

${ }^{a}$ Universidad Nacional Autónoma de México (UNAM), Facultad de Odontología, División de Estudios de Posgrado e Investigación (DEPeI), Laboratorio de Bioingeniería de Tejidos, Circuito Exterior, $s / n$, Cd. Universitaria, 04510, Coyoacán, CDMX, México

${ }^{b}$ Universidad Autónoma Metropolitana-Iztapalapa, Departamento de Química, Av. San Rafael Atlixco, No. 186, Iztapalapa, Ciudad de México, México

'Universidad Nacional Autónoma de México (UNAM), Facultad de Odontología, División de Estudios de Posgrado e Investigación (DEPeI), Laboratorio de Materiales Dentales, Circuito Exterior, s/n, Cd. Universitaria, 04510, Coyoacán, CDMX, México

${ }^{d}$ Instituto de Fisiología Celular, Circuito Exterior, s/n, Cd. Universitaria, 04510, Coyoacán, CDMX, México

'Instituto de Investigaciones en Materiales, Circuito Exterior, s/n, Cd. Universitaria, 04510, Coyoacán, CDMX, México

Received: May 15, 2020; Revised: July 30, 2020; Accepted: September 09, 2020

Composite materials are used in bone tissue engineering because they mimic the structure of the extracellular matrix of bone. In this work, polylactic acid (PLA) fiber scaffolds prepared by air-jet spinning technique, were doped with different concentrations of SBA-15 ceramic $(0.05,0.1$, and $0.15 \mathrm{wt} \%)$. The SBA-15 ceramic powder was made by the Sol-Gel process. Physicochemical characterization of PLA, SBA-15, and composite fiber scaffold was done by XRD, SEM, BET, FTIR, TGA, mechanical test, and biocompatibility assay, which were performed in a cell culture model with osteoblast cells. Our results showed a random nanofibers composite scaffold with an improvement in the physicochemical properties. The PLA fiber diameter increases as increases the content of SBA-15, and the mechanical properties were dose-dependent. SBA-15 shows the well-ordered mesoporous hexagonal structure with a pore size of $5.8 \pm 0.2 \mathrm{~nm}$ and a specific surface area with a value of $1042 \pm 89 \mathrm{~m}^{2} / \mathrm{g}$. PLA fibers and composites have thermal stability up to $300^{\circ} \mathrm{C}$, and thermal decomposition in the range $316-367^{\circ} \mathrm{C}$. In vitro biocompatibility results showed that PLA/SBA-15 composite scaffold had no cytotoxicity effect in terms of cell adhesion and viability of osteoblast cells. Furthermore, the doped SBA-15 with $0.05 \%$ wt onto the polymer matrix could be useful in biomedical applications for bone tissue engineering.

Keywords: Silica mesoporous material, air-jet spinning, fiber spun mats, composites scaffold, cell-material interaction, bone tissue engineering.

\section{Introduction}

Bone defects are a major health concern worldwide due to the damage of bone tissue by diseases, aging, or sport-related injuries, requiring the reconstruction by surgical therapies consisting of standard grafts materials from different origins (homologous, heterologous or autologous) to restore the bone tissue ${ }^{1}$. However, when conventional treatments could not restore the complex functional structure and lack the promotion to regenerate the affected bone structures, bone tissue engineering has emerged as a promising technique for stimulating the regeneration of bone by the development of biomaterials scaffolds that could mimic the extracellular matrix (ECM) of bone, acting as a temporary framework providing a suitable environment for normal cell growth and

*e-mail: marcoalv@unam.mx hence helps in bone tissue regeneration ${ }^{2}$. In the last years, in bone tissue engineering field, numerous efforts to create the ideal bone ECM analog structure, beginning from flat monocomponent to 2D fibers made of synthetic polymers (i.e., polycaprolactone, polylactic acid, polystyrene, polyurethane, etc.), due to their unique properties -i.e., high surface area to volume ratio, fully fluid and molecular transport- that enhanced cellular interactions, protein adsorption and facilitating good biocompatibility, in order to mimic the complex organization of fibrillary interphase of the native bone tissues ${ }^{3-6}$.

Furthermore, the custom design of functional, active spun fibers properties is crucial to regulate cellular behavior of the scaffolds and to achieve cell interactions similar to those in native $\mathrm{ECM}^{7,8}$. Recent developments in material 
science manufacturing allow alternatives to address several challenges in the treatment of bone tissue. An example of such advancement is the air-jet spinning (AJS) technique, emerging for its flexible simplicity as highly and low-cost processes able to manipulate materials by utilizing gas pressure forces, giving the unique opportunity to design sheet-like platforms that could mimic the densely packed fibrillary structure of the ECM that address and promote better cell adhesion, cell spreading and cell fate during regeneration processes ${ }^{9-11}$. However, despite a fine control of the spinning process by the AJS that could guarantee tunable physicochemical and mechanical properties, polymer spun fibers show several limitations in terms of bioactivity, thus negatively influencing communication mechanisms between cells.

Recently, several studies underlining the opportunity to process biodegradable polymers as PCL, PU, PVA, or PLA with bioceramics (i.e., hydroxyapatite, silica, zirconium. $\mathrm{TiO}_{2}$ ) to control fiber architecture on a nanoscale better, and mainly providing peculiar bioactive signals to better address cell activities towards selected bone tissue phenotype 8,12-14. $^{\text {. }}$. In this context, bioactive mesoporous materials with pore sizes in the range of $2-50 \mathrm{~nm}$ have attracted significant attention due to their structural characteristics, including their uniform pore size distribution, high specific surface area (typically $1000 \mathrm{~m}^{2} / \mathrm{g}$ ), high porosity (pore volumes $0.5-1.5 \mathrm{~cm}^{3} / \mathrm{g}$ ), well ordered, tunable pores (usually $2-15 \mathrm{~nm}$ pore diameter), and also for its excellent biocompatibility and osteoconductivity characteristics that make it suitable for bone tissue regeneration ${ }^{15-17}$. One example of this mesoporous material is Santa Barbara Amorphous no. 15 (SBA-15), a bioceramic synthesized in acidic conditions on a triblock copolymer template ${ }^{18}$. SBA-15 exhibits cylindrical channels (pores) with pore diameters between 5 and $30 \mathrm{~nm}$, arranged in 2D meso-hexagonal structures that are uniformly distributed over the surface, such pores give it a high surface area $\left(100-1000 \mathrm{~m}^{2} / \mathrm{g}\right)$ and robust silica walls (3-6 nm). These characteristics allow a better functionalization with different biomolecules, representing a significant advantage compared to other non-porous inorganic compounds ${ }^{19}$. Previous studies have reported the bioactive behavior of SBA-15 demonstrating the formation of carbonated hydroxyapatite layers attributed to the presence of the silanol group which originates nucleation sites on the surface of SBA-15, and the analysis helped to determine that SBA-15 is a bioactive mesoporous material with potential for regeneration of bone tissue $e^{20,21}$. On the other hand, polylactic acid (PLA) is a polymer widely used in biomedical applications, approved by the Food and Drug Administration (FDA) for applications in orthopedic devices ${ }^{22}$, which is currently being used as scaffolding for the regeneration of the bone tissue ${ }^{23-28}$. However, its hydrophobic nature, its low stability, and its relatively low mechanical properties have limited the applications of this polymer, in particular as bone material ${ }^{29}$. One of the challenges associated with developing scaffolds for bone tissue engineering is that no single material meets the osteoconductive and osteoinductive properties adequately to promote bone cells to adhere, grow, and proliferate. Besides, composites materials with desired properties consisting of organic and inorganic components have been proposed to be a solution to this problem and gained much attention due to the advantages of combining their features, and the possibility to obtain required bioactivity, degradation behavior, and mechanical properties for bone tissue engineering scaffold ${ }^{30}$. In this context, for addressing PLA scaffold limitations, we propose the use of the SBA-15 as a bioceramic structure that provides inorganic reinforcement and improves the physicochemical and mechanical properties of the biodegradable polymer for the synthesis of the spun bioactive scaffold by using the AJS, representing an attractive and alternative technique for fabricated new composite scaffolds (PLA/SBA-15). Furthermore, the effects of the PLA/SBA-15 composite scaffolds on the initial response biocompatibility of human osteoblast cells were evaluated to use the material for bone tissue engineering.

\section{Experimental Section}

\subsection{Materials}

The template for directing the mesostructure of SBA-15 was (poly(ethylene glycol)-block-poly(propylene glycol)block-poly(ethylene glycol) triblock copolymer known as Pluronic P-123 $\left(\mathrm{EO}_{20} \mathrm{PO}_{70} \mathrm{EO}_{20}\right.$ with average $\mathrm{Mn} \sim 5800$, Sigma-Aldrich) and tetraethyl orthosilicate (TEOS, SigmaAldrich) used as the silica source ${ }^{19}$. During the synthesis of SBA-15, hydrochloric acid (37\% Sigma-Aldrich) and deionized water (Millipore ${ }^{\circledR}$ Milli-Q water system) was used. For the extraction washes, Ethanol $\left(\mathrm{C}_{2} \mathrm{H}_{6} \mathrm{O} 99.5 \%\right.$, Sigma-Aldrich) and deionized water (Millipore $\AA$ Milli-Q water system) were used. To prepare the polymeric membrane, the polylactic acid solution was used (PLA, Mw =192,000, Nature Works D2002).

\subsection{Synthesis of SBA-15}

The SBA-15 mesoporous silica ceramic was synthesized by the sol-gel technique according to previously reported methods ${ }^{20,21}$. The template solution was produced dissolving $8 \mathrm{~g}$ of the surfactant Pluronic ${ }^{\circledR} \mathrm{P} 123$ in $270 \mathrm{~mL}$ of deionized water, and $20 \mathrm{~mL}$ of $1.7 \mathrm{M} \mathrm{HCl}$ was added until a bright and homogeneous solution was obtained under magnetic stirring at $40^{\circ} \mathrm{C}$. Once the surfactant was dissolved entirely, $16 \mathrm{~mL}$ of TEOS was added as a silica source, and the mixture was maintained under magnetic stirring at $40^{\circ} \mathrm{C}$ temperature for $12 \mathrm{~h}$. Afterward, the resulting suspension mixture was subjected to aging under static conditions at $70{ }^{\circ} \mathrm{C}$ for $24 \mathrm{~h}$. After aged, the SBA-15 material was collected by filtration, washed with deionized water, and for removing the surfactant dried powder was treated with several washing cycles of organic solvents $\left(\mathrm{H}_{2} \mathrm{O}\right.$-Ethanol 50:50). After this process, the ceramic was filtered and kept at $60^{\circ} \mathrm{C}$ for $24 \mathrm{~h}$ to remove moisture and followed by calcination in air at $550{ }^{\circ} \mathrm{C}$ with a heating rate of $\left(1^{\circ} \mathrm{C} / \mathrm{min}\right)$ for $8 \mathrm{~h}$.

\subsection{PLA and PLA/SBA-15 polymeric solution}

The polylactic acid (PLA) polymeric solutions of $10 \% \mathrm{wt}$ were prepared as follows ${ }^{1}$ : PLA pellets were dissolved in chloroform $\left(\mathrm{CHCl}_{3}\right)$, stirring the mixture over a day and then adding acetone and stirring over 20 min until a homogeneous solution was obtained. The volume ratio of chloroform/acetone was 3:1 for all samples. For PLA/ SBA-15 composites, the same procedure was followed, but 
at the moment of dissolving PLA, the mesoporous ceramic of SBA-15 was added in different concentrations ${ }^{19}(0.05 \%$, $0.1 \%$, and $0.15 \% \mathrm{wt}$ ).

\subsection{PLA and PLA/SBA-15 fiber spun composite scaffolds synthesis}

Fibrous spun scaffolds were produced via the air-jet spinning process from PLA and PLA/SBA-15 polymeric solutions. The air-jet spinning process utilizes a specialized spinning system nozzle, such as a commercial airbrush, a surface for collecting polymer fibers, and compressed gas through which the polymer solution and a pressurized gas are simultaneously ejected to form the fiber morphology $y^{3,10}$. In all cases, the polymeric solution was placed in a commercially available airbrush TC-4176 with a $0.3 \mathrm{~mm}$ nozzle diameter and with a gravitational feed of $7 \mathrm{~mL}$ of each polymeric solution to synthesize the fiber scaffold. The airbrush was connected to a pressurized argon tank (CAS number 7740-37, concentration $>99 \%$, PRAXAIR Mexico). For fiber deposition, a pressure of $30 \mathrm{psi}$ with an $11 \mathrm{~cm}$ distance from the nozzle to the target was maintained constant with $15 \mathrm{~min}$ of deposit at a ratio of $1 \mathrm{~mL} / \mathrm{min}$ with $25^{\circ} \mathrm{C}$ of room temperature and $30 \%$ of humidity. After the deposit, the spun membranes were placed in a hermetic conservation unit to avoid direct contact with sunlight.

\subsection{Physicochemical characterization of materials}

The ordered mesoporous framework of the synthesized material was assessed by powder small-angle X-ray diffraction (XRD) in a Siemens D-500 diffractometer operating with $\mathrm{Cu} \mathrm{K} \alpha$ radiation $(\mathrm{k}=1.5406 \AA)$ at $34 \mathrm{kV}$ and $25 \mathrm{~mA}$. The diffractograms were collected over the $0.5^{\circ}-8.0^{\circ} 2 \Theta$ range with a step size of $0.02^{\circ}$, and a contact time of $5 \mathrm{~s}$ per step.

The structure of SBA-15 mesoporous material was characterized via transmission electron microscopy (JEOL JEM-2100 microscope) with a $120 \mathrm{kV}$ acceleration voltage for the electron beam. The morphology of the SBA-15 mesoporous ceramic and the fiber spun membrane of PLA and PLA/SBA-15 composites scaffold were examined using a scanning electron microscope (JEOL JSM-6700F microscope) with a $20 \mathrm{kV}$ acceleration voltage for the electron beam. The element analysis by EDS was by $300 \mathrm{sec}$. of scanning time with automatic live correction. SEM images were analyzed to measure the size diameters of the PLA fibers and the diameters of the PLA/SBA-15 composite on the micrographs by using the Image $\mathrm{J}$ software choosing 25 locations randomly from the SEM image.

The chemical structure of the samples was analyzed using a Shimadzu IR Affinity-1S Fourier transform infrared (FTIR) spectrometer with a wavelength range of 400 to $4000 \mathrm{~cm}^{-1}$. The surface characterization of SBA-15 material was carried out by nitrogen adsorption/desorption analyses performed at $77 \mathrm{~K}$ using an ASAP 2000, Micromeritics. The specific surface area was calculated using the Brunauer-EmmettTeller (BET) method in the relative pressure range of $P$ / $P 0=0.02-0.3$. The pore size distributions were calculated from the desorption branch using the Barrett-Joyner-Halenda $(\mathrm{BJH})$ model, and the pore size was calculated from the peak position of the distribution curve. The pore volume was measured at the $P / P 0=0.999$ position.

Thermogravimetric analysis was done using TGA Q500 equipment (TA Instruments, U.S.A). Platinum $100 \mu \mathrm{L}$ baskets were tared before automatically to weight $8 \mathrm{mg}$ of the sample to be analyzed. After loading, the furnace was closed, and the initial temperature was set to $20^{\circ} \mathrm{C}$ with the isothermal stage of 3 minutes before temperature increases. After thermal stabilization, a thermal increment of $10^{\circ} \mathrm{C}$ per minute was done until a final temperature of $1000{ }^{\circ} \mathrm{C}$ was reached. Data were analyzed using TGA software (Universal V4.5A TA Instruments) to identify onset points (To) and maximum mass loss point (Tmax). By calculating the 1 st derivate of weight percentage $\left(\% /{ }^{\circ} \mathrm{C}\right)$, inflection points were calculated (Tp).

Uniaxial tensile tests were done in universal testing machine INSTRON 5567 at $20^{\circ} \mathrm{C}$ and $50 \%$ rh. Fiber spun membranes were cut into dog bone-shaped samples according to ASTM D1708-10 2011 with a narrow section $5 \mathrm{~mm}$. The average specimens' thickness was not constant. A crosshead speed of $1 \mathrm{~mm} / \mathrm{min}$ was used. Twelve specimens by a group of each composition were tested using a $5000 \mathrm{~N}$ load cell. The initial grip separation was measured for each sample (Lo). Young's modulus, tensile strength and tensile strength strain, yield point, resilience, toughness, and ultimate strain and stress were calculated using stress-deformation curves. Resilience and toughness were obtained by measuring the area under the stress-strain curve of the elastic region and the plastic region using Curve Expert Software.

\subsection{Biological characterization of the spun membranes}

Human fetal osteoblast cells (hFOB, 1.19 ATCC CRL11372) were used to evaluate the cell biocompatibility response of PLA fibers spun mat, and PLA/SBA-15 spun composite scaffolds. hFOB cells were cultured in $75 \mathrm{~cm}^{2}$ cell culture flasks containing a 1:1 mixture of Ham's F12 Medium Dulbecco's Modified Eagle Media (DMEM, Sigma-Aldrich, St. Louis, USA), supplemented with $10 \%$ fetal bovine serum (FBS, Biosciences, USA), $2.5 \mathrm{mM}$ L-glutamine and antibiotic solution (streptomycin $100 \mu \mathrm{g} / \mathrm{mL}$ and penicillin $100 \mathrm{U} / \mathrm{mL}$, Sigma-Aldrich). The cell cultures were incubated in a $100 \%$ humidified environment at $37^{\circ} \mathrm{C}$ in an atmosphere of $95 \%$ air and $5 \% \mathrm{CO}_{2}$. $\mathrm{hFOB}$ on passage 2-6 were used for all the experimental procedures.

Before the biological assays, the PLA fibers spun mat, and PLA/SBA-15 spun composite scaffolds were placed in 24 cell culture plates and sterilized by immersion in $70 \%$ of ethanol (v/v) with an antibiotic solution (streptomycin $100 \mu \mathrm{g} / \mathrm{mL}$ and penicillin $100 \mathrm{U} / \mathrm{mL}$ ) for $30 \mathrm{~min}$. After sterilization, nanofiber scaffolds were rinsed with PBS, distilled water three times, and air-dried.

The cell viability of $\mathrm{hFOB}$ cells plated at a concentration of $1 \times 10^{4}$ cells $/ \mathrm{mL}$ in triplicate onto PLA fibers spun mat and PLA/SBA-15 spun composite scaffolds were checked by the cell counting kit-8 (CCK-8) assay for $1,3,5$, and 7 days of culture. This assay is based on the ability of the dehydrogenated enzyme to reduce a water-soluble tetrazolium salt [2-(2-methoxy-4-nitrophenyl)-3-(4-nitrophenyl)-5-(2, 4-disulfophenyl)-2H-tetrazolium, monosodium salt] (WST-8) 
to a water-soluble formazan dye (orange-colored product) in the cell culture medium. The concentration of the formazan product is directly proportional to the number of metabolically active cells. hFOB cells seeded onto PLA fibers spun mat, and PLA/SBA-15 spun composite scaffolds at the prescribed times the samples were washed with PBS and incubated with $400 \mu \mathrm{L}$ fresh culture medium containing $40 \mu \mathrm{L}$ of the cell proliferation reagent CCK- 8 for $4 \mathrm{~h}$ at $37^{\circ} \mathrm{C}$. After this time, $200 \mu \mathrm{L}$ of the supernatant was removed, and placed in a 96 well plate for ELISA assays to obtain the absorbance quantified by spectrophotometry at $450 \mathrm{~nm}$ (ChroMate, Awareness Technology). The results of cell viability were reported as the percent of cell viability, considering the 100\% of the control culture of hFOB cells seeded onto PLA fibers scaffold. During the experimental time, the culture medium was exchanged every third day.

The cell-material interaction of hFOB cells seeded at $1 \times 10^{4}$ cells $/ \mathrm{mL}$ onto PLA/SBA- 15 with the concentration

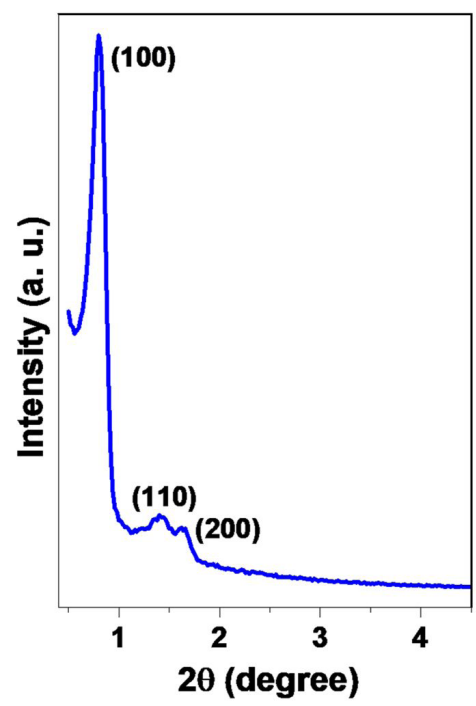

Figure 1. X-ray diffraction patterns of SBA-15 mesoporous ceramic material. of $0.05 \%$ spun composite scaffold was examined using SEM and fluorescence microscopy (AMSCOPE) after $24 \mathrm{~h}$ of cell culture. For SEM analysis, at the end of the incubation culture time, fiber spun membranes were washed three times with PBS, fixed with $4 \%$ formaldehyde for $1 \mathrm{~h}$ and then dehydrated with a graded series of ethanol (25-100\%) and air-dried. The samples were sputter-coated with a thin layer of gold and examined by SEM. For fluorescence microscopy, before seeding onto fiber composite, the hFOB culture cells were incubated with CellTracker ${ }^{\mathrm{TM}}$ Green CMFDA (5-chloromethylfluorescein diacetate) in phenol red-free medium at $37^{\circ} \mathrm{C}$ for $30 \mathrm{~min}$. Subsequently, the cell culture was washed with PBS and incubated for $1 \mathrm{~h}$ in complete medium. After recovery, hFOB cells were trypsinized and counted to the desired cell concentration $\left(1 \times 10^{4}\right.$ cells $\left./ \mathrm{mL}\right)$ and incubated for $24 \mathrm{~h}$ onto PLA/SBA-15 spun composite scaffold and evaluated for spreading and cell-material interaction.

\subsection{Statistical analysis}

To evaluate for statistically significant differences, one-way analysis of variance (ANOVA), with Tukey's test were employed for comparison between conditions with a $p$-value of less than 0.05 was considered statistically significant.

\section{Results and Discussion}

\subsection{Characterization of SBA-15 ceramic}

The XRD pattern of synthesized SBA-15 mesoporous ceramic is shown in Figure 1. The pattern indicated three well-resolved Bragg diffraction peaks: one in $~ 1.038$ degrees, that correspond to $\left(\begin{array}{lll}1 & 0 & 0\end{array}\right)$ plane, second peak at $\sim 1.62$ correspondings to $\left(\begin{array}{lll}1 & 1 & 0\end{array}\right)$ plane and the third peak at $\sim 1.84$ that correspond to $\left(\begin{array}{l}2 \\ 0\end{array} 0\right)$ plane, confirming the highly ordered 2D hexagonal structure (P6mm) of the SBA-15 mesoporous ceramic $^{31-33}$. FE-SEM images analyzed the morphology of the SBA-15 showed in Figure 2. The micrographs showed the surface of SBA-15, where the characteristic lamella arrangement with open hexagonal shape characteristic of
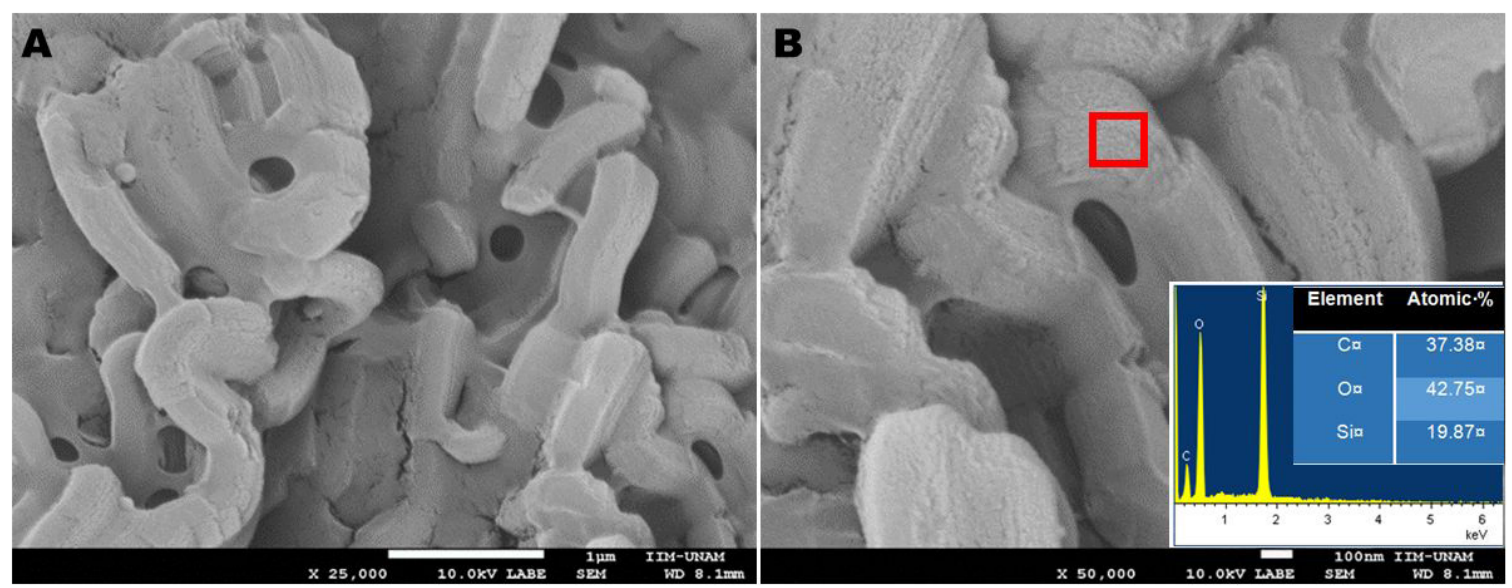

Figure 2. FE-SEM images micrographs of SBA-15 mesoporous ceramic material (A and B). The red box showed the area of the element analysis by EDS of carbon, oxygen, and silicon. 

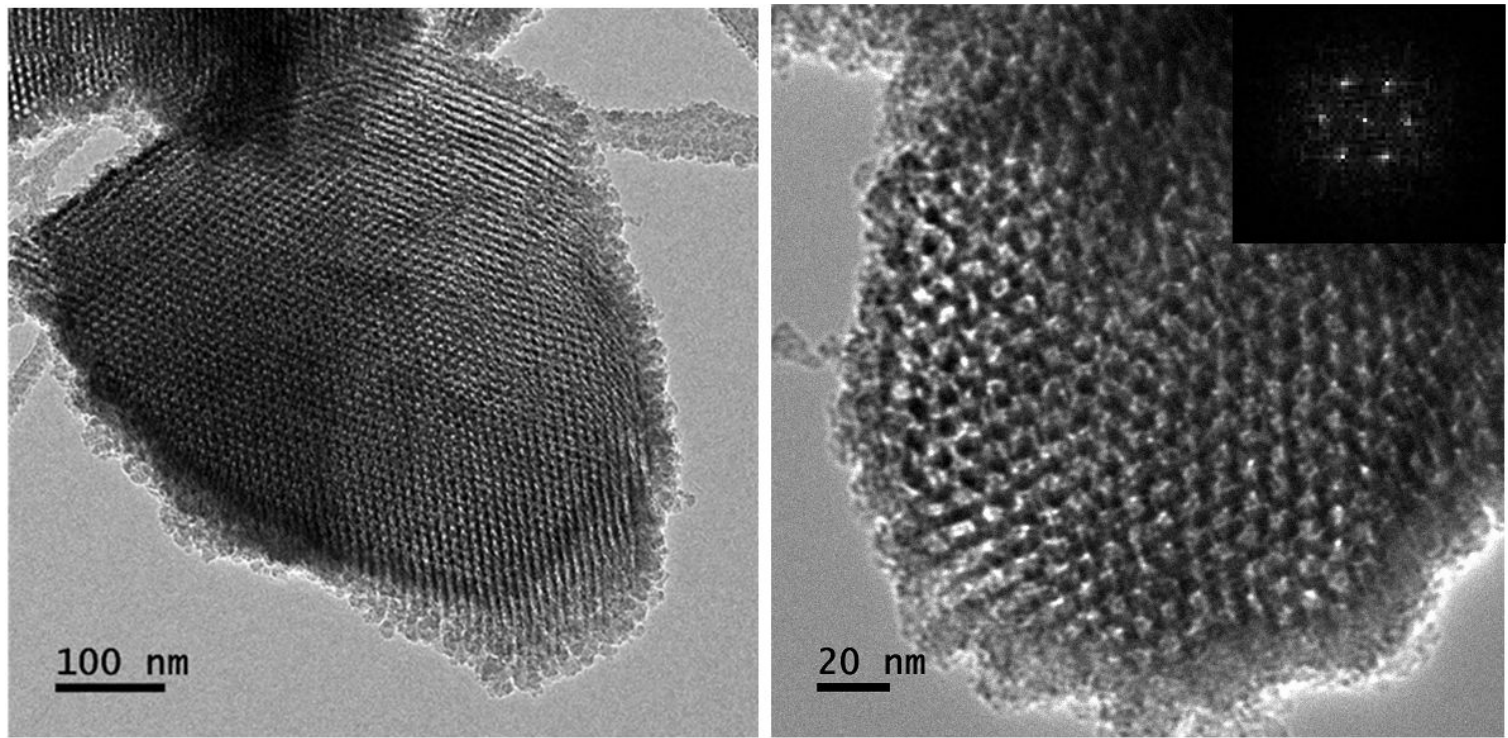

Figure 3. TEM micrographs of SBA-15 mesoporous ceramic material.

this type of mesoporous ceramic is observed ${ }^{34,35}$. Moreover, a random specific area (red box) was selected to perform an EDS analysis, indicating the elements such as silicon, oxygen, and carbon, that correspond to the chemical structure of the synthesized SBA-15. Furthermore, TEM micrographs of the structure of SBA-15 material show the hexagonal well-ordered mesoporous structure with pores size of $\sim 5.8 \pm 0.2 \mathrm{~nm}(\text { Figure } 3)^{36,37}$.

Figure 4 shows the surface properties for the SBA-15 mesoporous material obtained by $\mathrm{N} 2$ adsorption isotherms. The isotherm is typical for this kind of mesoporous material and can be attributed to the type IV in BDDT classification and is also observed the shape hysteresis loop with parallel adsorption and desorption branches that indicate the cylindrical mesopores effect with narrow pore size distribution. The surface area and average Barrett-Joyner-Halenda (BJH) pore diameter of SBA-15 was $1042 \pm 89 \mathrm{~m}^{2} / \mathrm{g}$ and $5.5 \pm 0.2 \mathrm{~nm}$, respectively. These results are in agreement with those in the reported literature for syntheses of silica mesophases ${ }^{31,33,38-40}$.

\subsection{Characterization of PLA/SBA-15 composite scaffold}

Fiber composite scaffolds are proposed for mimic the extracellular matrix of bone because the presence of bioceramics could enhance the bioactivity for progenitor and bone cells, thus, in this study, we try to combine a polymeric solution of PLA for mimic the fibrillary structure of collagen fibers, with the incorporation of SBA-15 mesoporous ceramic as bioactive ceramic for synthesized a fiber composite by air-jet spinning. The analysis by SEM micrographs of PLA fiber spun mat and PLA/SBA-15 fiber composites are shown in Figure 5. The morphology of all spun mats displayed a similar fibrous appearance with some beads; meanwhile, the average diameter of fibers showed some differences. The average diameter of $424 \pm 26 \mathrm{~nm}$ for pure PLA fiber increases to $477 \pm 34 \mathrm{~nm}$ for PLA/SBA-15 (0.05\%), to $522 \pm 38 \mathrm{~nm}$ for PLA/SBA-15 (0.10\%) and $488 \pm 35 \mathrm{~nm}$ for PLA/SBA-15

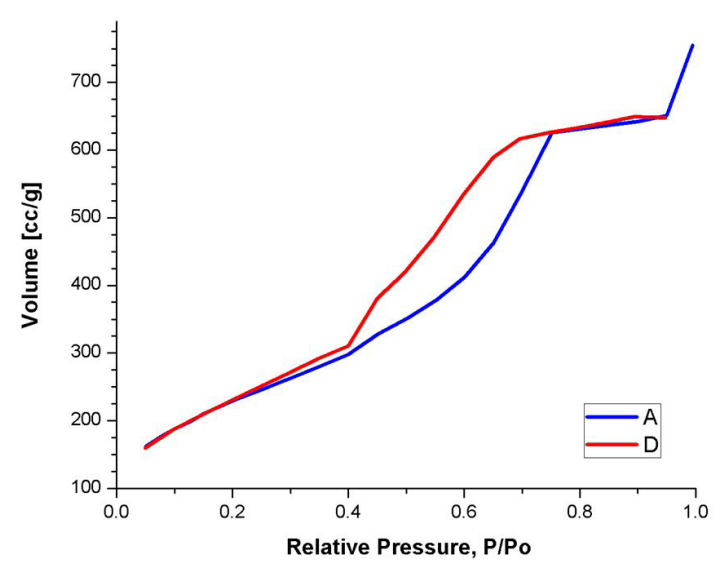

Figure 4. Nitrogen adsorption-desorption isotherms of SBA-15 mesoporous ceramic material.

$(0.15 \%)$ respectively ${ }^{41-43}$, with a rough surface that could be attributed to the distribution of SBA-15 mesoporous ceramic along with the PLA fiber.

In the corresponding SEM image of PLA/SBA-15(0.15 wt $\%)$ in Figure 5D, several beads are observed, which can be attributed to the fact that the SBA-15 $(0.15 \mathrm{wt} \%)$ particles filler into the PLA fibers and some more are agglomerated on to the surface of the PLA fibers creating beads. The effect of SBA-15 $(0.15 \mathrm{wt} \%)$ particles filling the PLA fibers results in one increase in effective diameter respect to the PLA fibers.

\subsection{FT-IR of PLA/SBA15 composite scaffold}

The identification of the functional groups of the SBA15, PLA, and PLA/SBA-15 composite was evaluated by FTIR (Figure 6). The spectra of the SBA-15 showed a band around $3400 \mathrm{~cm}^{-1}$ typical stretching vibrations of $\mathrm{OH}$ bond of the silanol groups ( $\mathrm{Si}-\mathrm{OH})$ and water that is still included in the ceramic; at approximately a wavelength of 

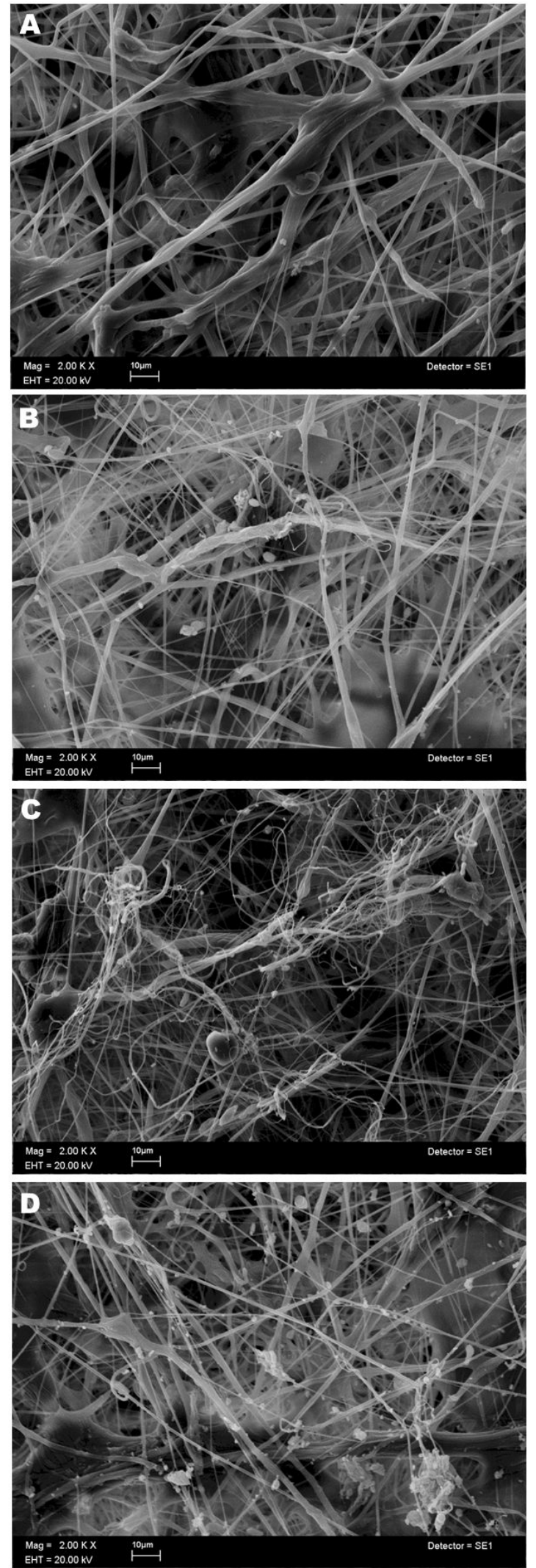
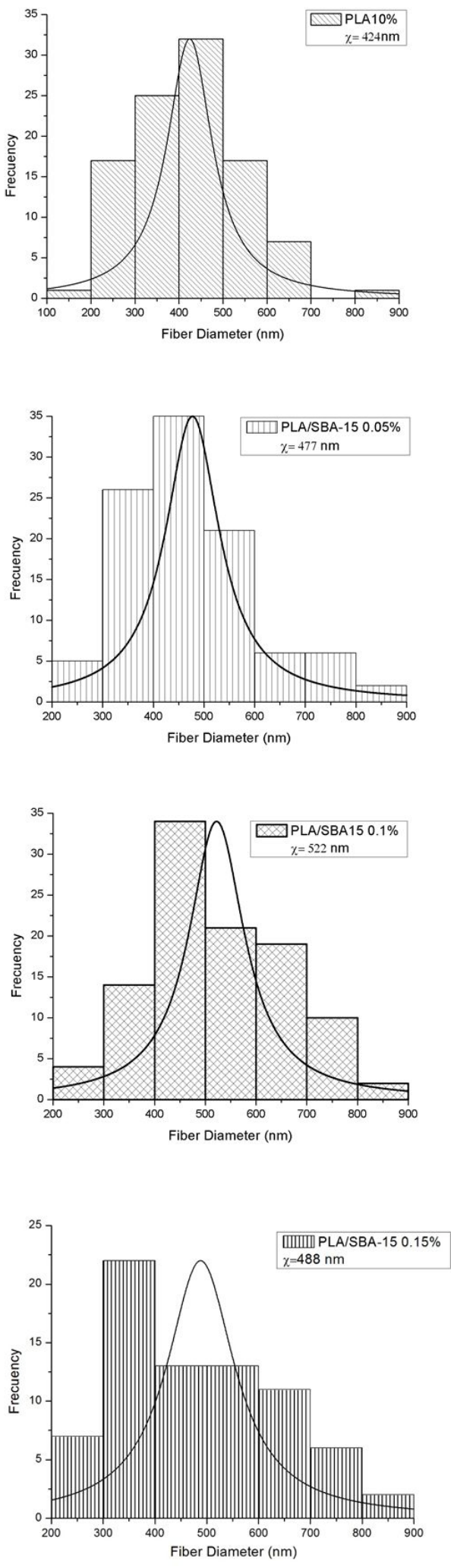

Figure 5. SEM images of the fiber morphology and estimation by a gauss fitting curve of diameter distribution of fiber size of PLA spun membrane of $10 \%$ (A) and PLA/SBA15 composite scaffold with $0.05 \%$ (B); $0.10 \%$ (C) and $0.15 \%$ (D). 


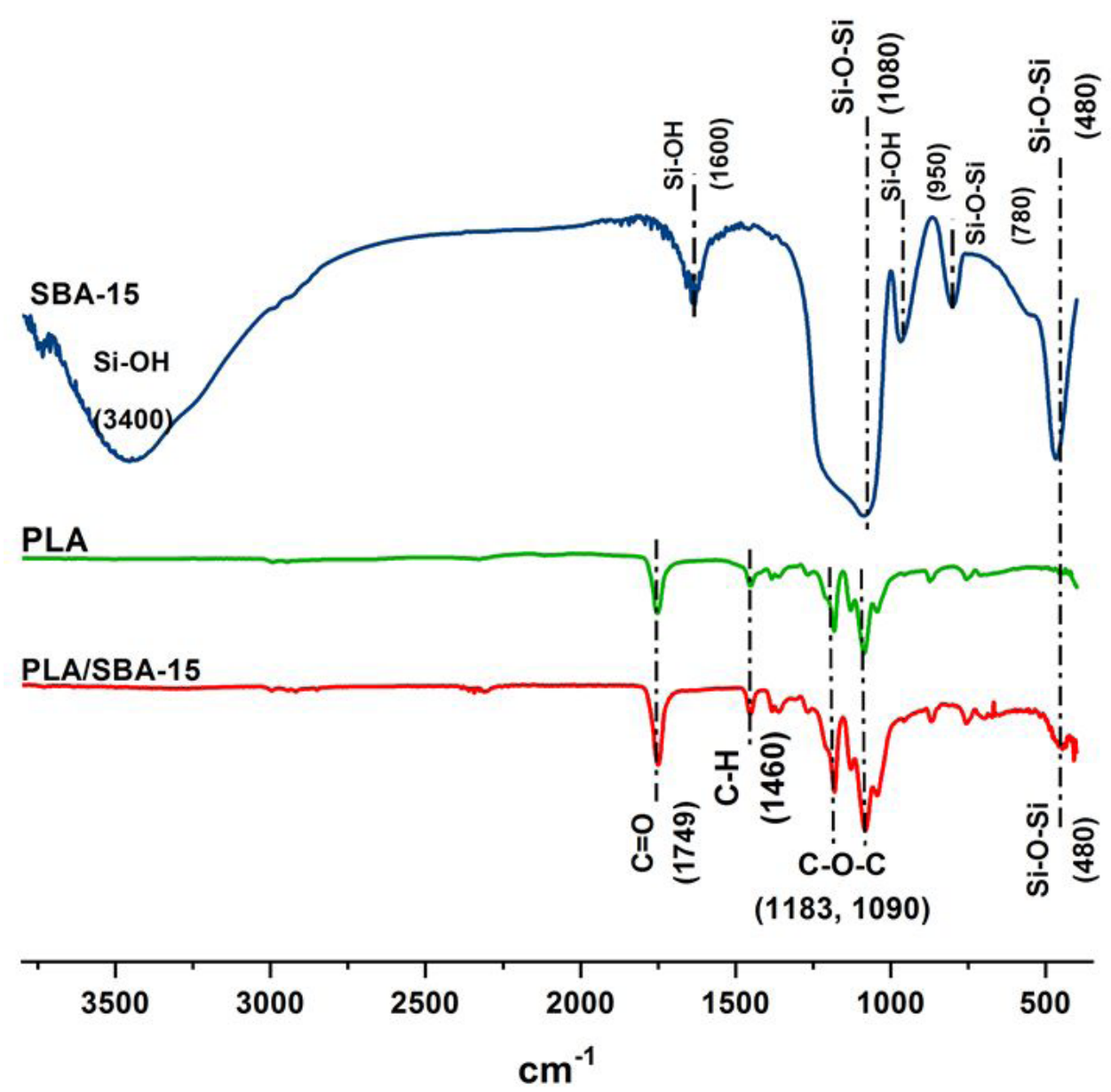

Figure 6. FTIR spectra of SBA-15 mesoporous ceramic material (a), PLA spun membrane of 10\% (b), and PLA/SBA15 composite scaffold (c).

$1600 \mathrm{~cm}^{-1}$, a band corresponding to the flexion vibration of the $\mathrm{OH}$ bond appears, the band at $1080 \mathrm{~cm}^{-1}$ is attributed to the vibration of elongation of the Si-O bonds, whereas the bands observed at $950 \mathrm{~cm}^{-1}$ are due to symmetric vibrations of the Si-OH bonds. Finally, the bands found at 750, and $480 \mathrm{~cm}^{-1}$ correspond to the flexural vibration of the O-Si-O bond. The bands obtained in the synthesis of SBA-15 are in agreement with other studies reported ${ }^{4-47}$. Moreover, PLA fibers present characteristic absorption bands at 1,749, 1,460, 1,183 , and $1,090 \mathrm{~cm}^{-1}$, which are attributed to $\mathrm{C}=\mathrm{O}$ stretching vibration, $\mathrm{C}-\mathrm{H}$ deformation vibration, and $\mathrm{C}-\mathrm{O}-\mathrm{C}$ stretching vibration in PLA ${ }^{48,49}$. Finally, the analysis by FT-IR of the PLA/SBA-15 fiber composite shows the adsorption of bands mostly attributed to the PLA and the adsorption of a new band at $480 \mathrm{~cm}^{-1}$ correspondings to the flexural vibration of the $\mathrm{Si}-\mathrm{O}$ bond, indicating the presence and incorporation of the SBA-15 on the morphology of the fibers ${ }^{44,46,48}$.

\section{TGA}

The thermal gravimetric analysis for the SBA-15 mesoporous ceramic, PLA fiber spun mat, and PLA/SBA-15 fiber composite is shown in Figure 7. In the TGA curve of
SBA-15 ceramics (Figure 7a); could be observed that in the range of 20 to $125^{\circ} \mathrm{C}$ there is the first region of loss of weight corresponding to the thermodesorption of physically adsorbed water by the mesoporous ceramics; within this range is found the body temperature $\left(37^{\circ} \mathrm{C}\right)$ where the thermogram shows an approximate loss of $2 \%$ on the weight. The second region in the temperature range of 125 to $300{ }^{\circ} \mathrm{C}$ it shows another weight loss attributed to the removal of the surfactant used for the synthesis of SBA-15 or to the silanol condensation and the third region in the temperature range 300 to $500^{\circ} \mathrm{C}$ corresponds to the thermal decomposition of the PLA material. Moreover, the TGA curve showed excellent thermal stability of the SBA-15 mesoporous ceramic ${ }^{50,51}$. Figure 7(b) showed the thermogravimetric profiles for the PLA fiber spun mat and PLA/SBA-15 composite fiber. Meanwhile, the PLA fiber spun mat began to decompose from $340^{\circ} \mathrm{C}$ and stabilized after $380^{\circ} \mathrm{C}^{52}$. The PLA/SBA-15 composite fibers show a slight decrease in the thermal stability that undergoes degradation in a single step up to approximately $300^{\circ} \mathrm{C}$ and stabilized after $360^{\circ} \mathrm{C}$; compared to PLA fibers because of the surface lamella-like morphology of SBA-15 structures mixed onto the polymer matrix could originate that polymer fiber could be more exposed to a phase with a rigid 
A

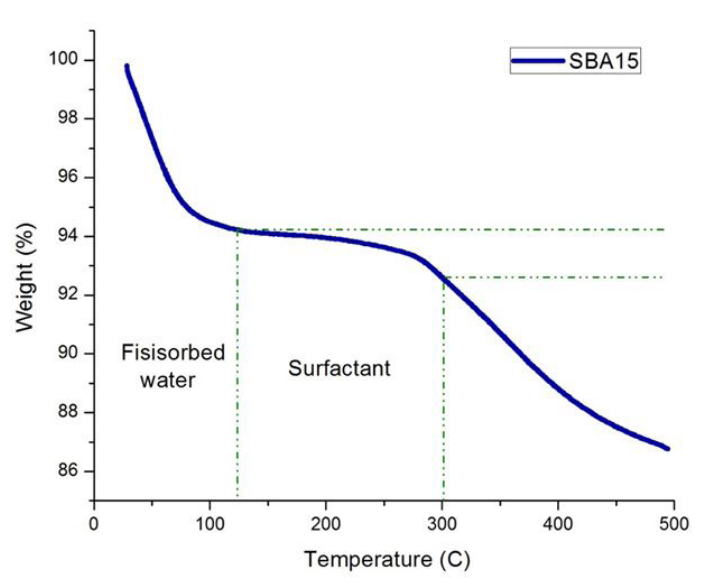

B

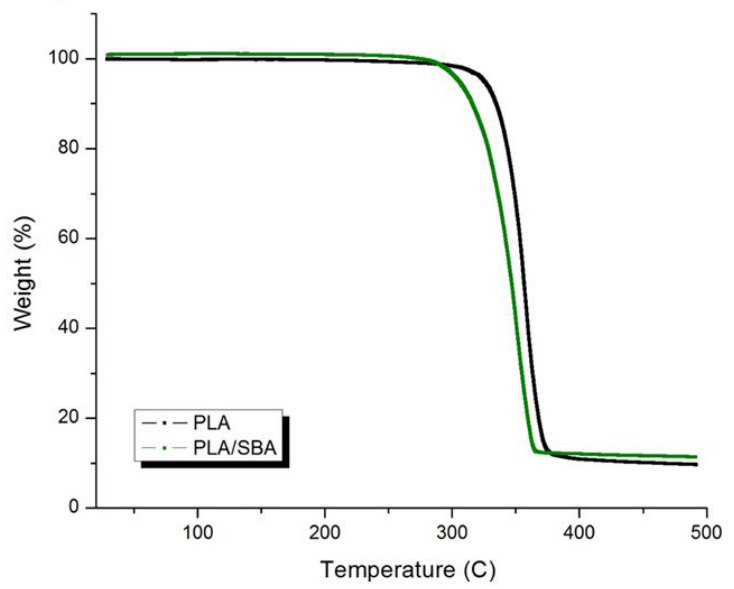

Figure 7. TGA of SBA-15 mesoporous ceramic material (A) and TGA of the PLA fiber spun mat of 10\%, and PLA/SBA-15 fiber composite (B).

and densely packed semicrystalline structure by mesoporous ceramic, moreover, in comparison with the TGA of SBA-15 ceramics (Figure 7a). In both cases, the residue is attributed to the char formation from the PLA; however, in the case of composites, the residue is also attributed to the SBA-15 nanoparticles. It can be seen that the PLA functioned as a protective polymer matrix, helping it to be thermally stable up to approximately $300^{\circ} \mathrm{C}$. This is in accordance with the thermal stability and decomposition of PLA and PLA composite-based materials. Reports showed that the onset degradation temperature decreased after adding inorganic filler, and this may be due to the decrement of molecular weight during mixing. This implied that the distribution of doped inorganic filler within the PLA matrix is homogeneous. Also, the dispersion of inorganic particles in the polymer matrix and the interfacial interactions between the polymer fibers and ceramics particles are key factors that are influencing the physical properties of the polymer matrix, which should be attributed to the nucleation effects of inorganic particles on the crystallization of PLA fibers ${ }^{53-55}$.

\subsection{Mechanical tests of PLA/SBA-15 composite scaffold}

The construction of an ideal scaffold must not only be able to mimic the structure of the ECM but also the matrices need to possess an adequate mechanical property for bone regeneration because the regeneration process is affected by mechanical force and stress distribution favoring or inhibiting the differentiation of cells. Evaluation of the elastic modulus, the maximum stress, the yield point, the resilience, and the toughness could allow producing mechanical properties that meet the requirements of the scaffold to be suitable for clinical applications ${ }^{6,56-58}$.

In our study, we analyzed the mechanical properties of the incorporation of SBA-15 mesoporous ceramic into the fiber composition of PLA spun mat. Figure 8 (a;b;c and d) shows a typical stress-strain curve of the scaffolds obtained where point 1 represents the coordinates of yield strain and the yield stress (yield point); point 2, represent the coordinates of the deformation at the beginning of the fracture of the

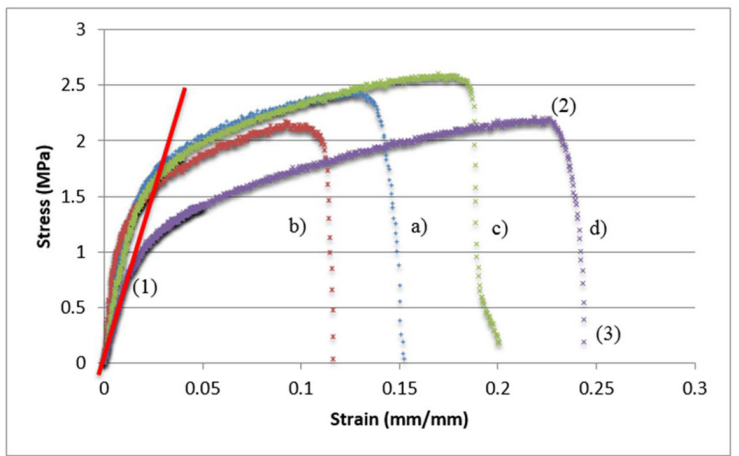

Figure 8. Typical stress- strain curve of : (a) PLA pure; (b) PLA/ SBA-15 (0.05 wt \%) (c) PLA/SBA-15 (0.10 wt \%) and (d) PLA/ SBA-15 $(0.15 \mathrm{wt} \%)$.

material and the maximum stress; and point 3 represent the ultimate strain or fracture strain and ultimate stress.

Figures 9 represent the mechanical properties of scaffolds prepared with different amounts of the SBA-15 concentration. The yielding stress (Figure 9A), maximum stress (Fig. 9B), and energy dissipation (resilience, Figure 9C) decrease linearly as concentration increases. Figure 9D shows that the PLA/ SBA-15 group $(0.05 \% \mathrm{wt})$ have an increase in the elastic modulus $(\sim 2 \%)$ concerning the pure PLA group, however, as the concentration increases, a gradual decrease in the modulus of Young is observed. The increased concentration of the SBA-15 caused the elastic modulus to decrease by $31 \%$ and $54 \%$ compared to pure PLA when SBA-15 concentrations increase to $0.10 \%$ and $0.15 \%$ by weight. The stress-strain curves showed elastic zones between 0.006 and $0.009 \mathrm{~mm} / \mathrm{mm}$, as shown in Table 1. In terms of deformation at the start of the fracture, the scaffolds exhibited a decrease of $10 \%$ with the concentration of $0.05 \%$ of SBA- 15 mesoporous ceramic, followed by an increase of $11 \%$ and $82 \%$ respectively for SBA- 15 with the concentrations of $0.10 \%$ and $0.15 \%$ by weight as showed in Figure 9E. The cross-linking exhibits rupture deformations ranging from 0.10 to $0.20 \mathrm{~mm} / \mathrm{mm}$, as observed in Table 1. The yield stress, resilience, and elastic 
modulus present statistically significant differences $(\mathrm{p}<0.05)$. This behavior indicates that if the SBA-15 content increases, the scaffold increases its ductility.

The scaffolds released considerable amounts of stored energy from 180 to $270 \mathrm{~kJ} / \mathrm{m}^{3}$, as seen in Figure 9F at the start of the resistance break, allowing for more significant ultimate deformation (Table 1).

The mechanical properties of the scaffolds are essential for influence tissue regeneration, and scaffolds with optimal elongation properties are necessary for the reconstruction
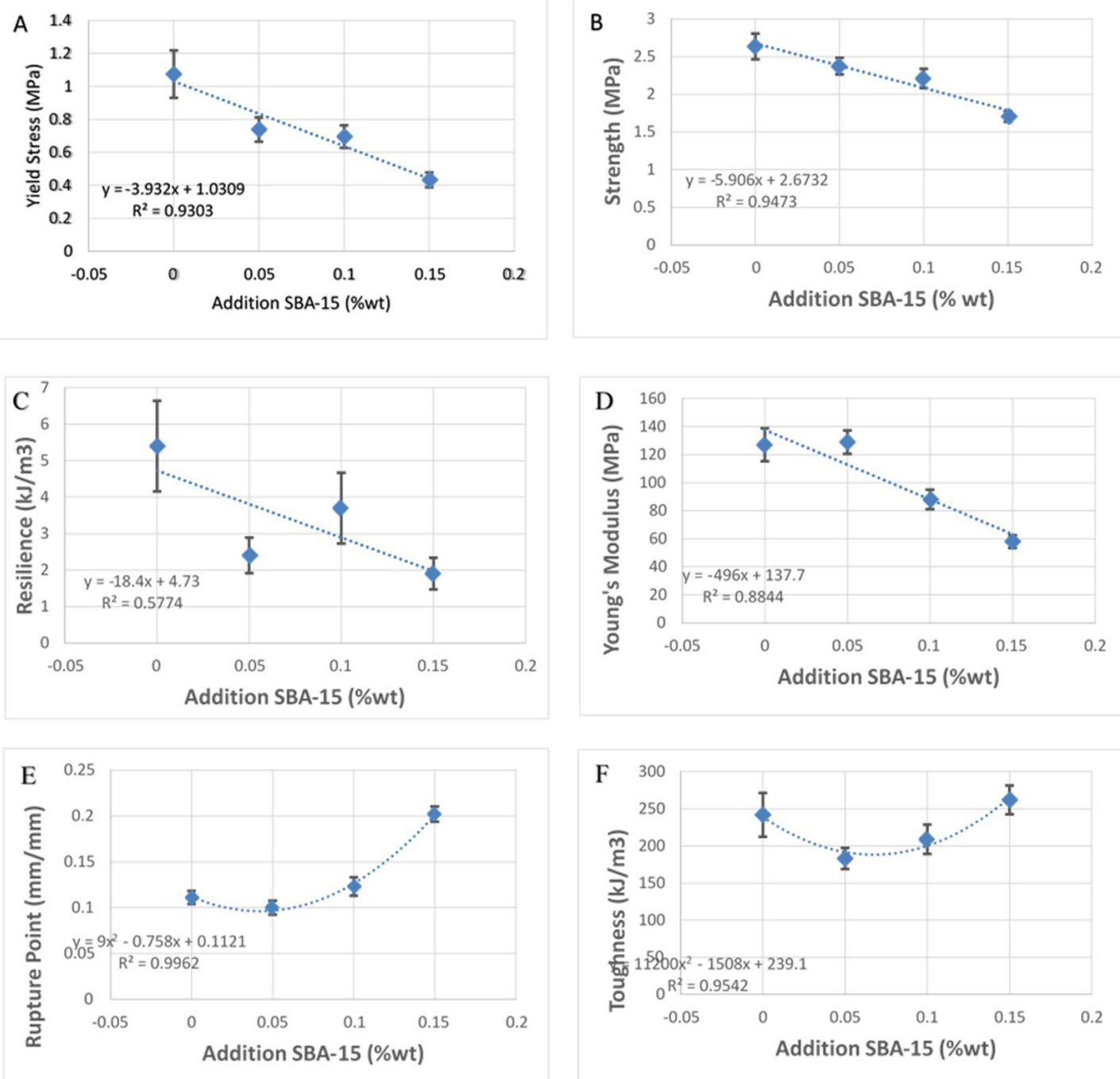

Figure 9. Mechanical properties of the PLA fiber spun mat of $10 \%$ and PLA/SBA-15 fiber composite. (A) Represent the Yield strength, (B) the strength, (C) the resilience, (D) the Young's Modulus, (E) the rupture point and (F) the Toughness behavior of the fiber spun membranes of PLA concerning the different percentages concentration of the SBA-15 mesoporous ceramic material.

Table 1. Mechanical Properties values obtained from scaffolding at different concentrations of SBA-15 mesoporous ceramic.

\begin{tabular}{lccccc}
\hline & Unit & PLA pure & \multicolumn{3}{c}{ Addition SBA-15 (\%) } \\
\hline & & & $0.05 \%$ & $0.10 \%$ & $0.15 \%$ \\
\hline Yield Strain & $\mathrm{mm} / \mathrm{mm}$ & 0.009 & 0.006 & 0.009 & 0.008 \\
\hline Yield Strength & $\mathrm{MPa}$ & 1.075 & 0.739 & 0.696 & 0.434 \\
\hline Rupture point & $\mathrm{mm} / \mathrm{mm}$ & 0.111 & 0.100 & 0.123 & 0.202 \\
\hline Strength & $\mathrm{MPa}$ & 2.635 & 2.372 & 2.209 & 1.705 \\
\hline Young's modulus & $\mathrm{MPa}$ & 127 & 129 & 88 & 58 \\
\hline Resilience & $\mathrm{kJ} / \mathrm{m}^{3}$ & 5.4 & 2.4 & 0.1 & 0.10 \\
\hline Ultimate Strain & $\mathrm{mm} / \mathrm{mm}$ & 0.134 & 0.120 & 0.350 & 0.433 \\
\hline Ultimate Stress & $\mathrm{MPa}$ & 0.395 & 0.406 & 209 & 262 \\
\hline Toughness & $\mathrm{kJ} / \mathrm{m}^{3}$ & 242 & 183 & & \\
\hline
\end{tabular}


of tissues that have normal stretching requirements and are necessary to perform everyday activities ${ }^{59,60}$. The maximum tensile strength or stress of cancellous bone is between 0.1 and $30.0 \mathrm{MPa}$, and the elastic modulus between 20 and $500 \mathrm{MPa}^{61}$. Using SBA-15 as filler material in PLA presented maximum stress values between 1.7 and $2.6 \mathrm{MPa}$ as well as a tensile elastic modulus between 60 and $120 \mathrm{MPa}$. This means that any of our mixtures $(0.05 \%, 0.10 \%$, or $0.15 \%)$ is suitable to implant as a scaffold in cancellous bone and could allow the osteoblastic cells to form new tissue.

Another factor that can affect the mechanical properties of the scaffold is the amount of filler because the fiberreinforced composites largely depend on the strong bonding between the matrix and fiber that will lead to improvement to the interfacial adhesion between them and therefore a stress transfer of fiber matrix and the fibers undertake the main load during the tensile process ${ }^{44,54}$. The surface area of the SBA-15 ceramic was $820 \mathrm{~m}^{2} / \mathrm{g}$ that would represent a surface covered by SBA- 15 of 4,8 , and $12 \mathrm{~m}^{2}$ of our used concentrations of $0.05 \%, 0.10 \%$, and $0.15 \%$ by weight respectively. Due to the high surface area of the filler, a significant increase in mechanical properties was expected, especially at a low percentage $(0.05 \%)$ because SBA- 15 could bond in the polymer and achieve effective reinforcement. However, increasing the load of SBA-15 can cause the stacking of its structure due to the strong van der Waals forces between them, so the average values decreased. The tensile ductility of materials is demonstrated by their ability to withstand large deformations before breaking completely. This property is increased when an organic matrix such as a polymer is reinforced with a filler material since the force is gradually transferred from the mortar matrix to the reinforcing fibers; in our case, when the composite material experiences a force. In this way, no catastrophic failure occurs in either the matrix or the fibers when the maximum stress is reached. Forces are essentially transferred away from highly stressed regions that suffer from decreased resilience. This is why our scaffolding experiences ultimate deformations stains ranging from 0.10 to $0.20 \mathrm{~mm} / \mathrm{mm}$ as the amount of SBA-15 increases, allowing to produce a biocomposite with excellent mechanical properties that agree with some other reports ${ }^{6,8,14,44,54-62}$.

\subsection{Biocompatibility characterization}

Scaffolds designed for biomedical applications such as the regeneration of bone tissues should mimic the structural characteristics of native ECM, having support functions, allowing cell proliferation ${ }^{63}$, and signaling the native tissue environment, to adapt to the optimal biological conditions that would enable colonization by progenitor cells and guide the regeneration ${ }^{64}$. After implantation, the scaffold should serve as growth tissue guidance, be able to withstand the loads to which normal tissue is subjected, and maintain a controlled degradation; thus, providing the pattern to be replaced it gradually by new tissue. Bone tissue is characterized by continuing constant remodeling processes formed by an organic and inorganic phase, i.e., type I collagen and hydroxyapatite respectively ${ }^{65,66}$. These two components form a composite structure at a nanometric scale that has instruction to the cells. Considering the above, reproducing both the characteristics and the phases has been a complicated challenge in the investigation of biomaterials for bone tissue applications. In this study, composite PLA/SBA-15 scaffolds were synthesized to imitate the bone ECM phases. Figure 10 represents the time course of the percent of cell viability of human fetal osteoblasts (hFOB) after seeded onto the PLA/SBA-15 fiber composite scaffold. At day 1 , there are a significant difference in the response of the hFOB among the PLA fiber spun mat and the PLA/ SBA-15 composite scaffolds. The PLA/SBA-15 with $0.05 \%$ and with $0.15 \%$ showed high cell viability as $143 \pm 6.71 \%$ and $134 \pm 15.43 \%$ in comparison with the PLA/SBA-15 with $0.10 \%$ that showed $80 \pm 8.46 \%$. At days 3,5 , and 7 , the PLA/SBA- 15 with $0.05 \%$ continue showing the highest cell viability in comparison with the PLA/SBA-15 with $0.05 \%$ and with $0.15 \%$ that showed low cell viability, as showed in Figure 10. This high values of cell viability of the PLA/ SBA- 15 with $0.05 \%$ indicate that this composite scaffold was more favorable for cell-material interactions in the first $24 \mathrm{~h}$ where the topographical surface could be an important key for the proliferation of osteoblasts because cellular adhesion constitutes the previous requirement of biocompatibility of the material and then favored the proliferation of the cells, coinciding with several reports indicating that it was crucial to incorporate nanosized ceramic components in engineered scaffolds to stimulate cell biocompatibility and to improve the ability of the composite to guide osteoprogenitor cells leading to new bone formation ${ }^{6,67-69}$.

Figure 11 showed the cell-material interaction and morphology of hFOB onto the PLA/SBA- 15 with $0.05 \%$ fiber composite analyzed by SEM and fluorescence microscopy. From the images could be seen that cells exhibited an excellent attachment and can spread well over the surface topography of the scaffold, and some cells interact directly with the fiber orientation-maintaining a close contact with the fiber by numerous filopodia, exhibiting a polyhedral morphology characteristic of osteoblasts. Moreover, the presence of SBA-15 mesoporous ceramic on the fiber-matrix could play a role in enhancing the cell-material interaction giving the cue for instruct the osteoblasts cells to the anchorage and proliferate over the surface. This cellular response is in agreement with the concept that the initial step in cell and biomaterial interaction is reflected in the ability of a

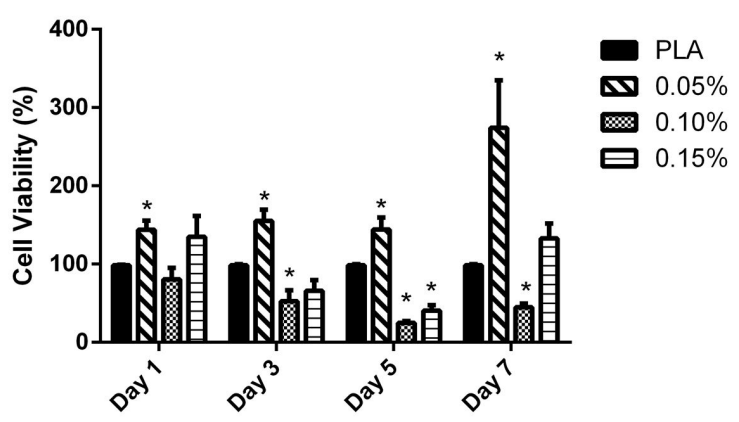

Figure 10. Percent of cell viability of hFOB cultured onto PLA/ SBA-15 fiber composite with different concentrations $(0.05 \%$, $0.10 \%$, and $0.15 \%$ ) at $1,3,5$ and 7 days of cell culture. Asterisk $\left({ }^{*}\right)$ mean that scaffolds showed a statistical significance $(\mathrm{p}<0.05)$. 

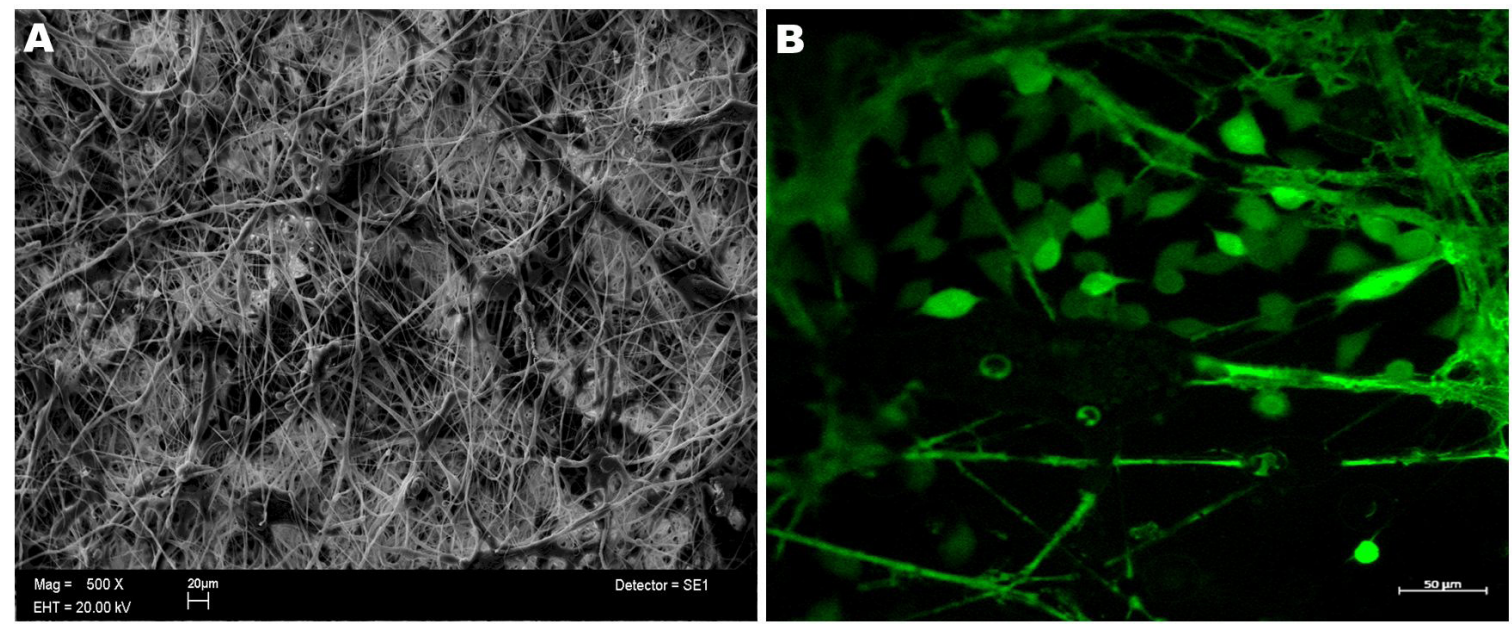

Figure 11. Representative SEM (A) and fluorescence (B) micrographs showing the morphology and spreading pattern interaction of hFOB cultured onto seeded PLA/SBA-15 fiber composite with $0.05 \mathrm{wt} \%$.

biomaterial to support cell attachment and spreading for its physicochemical properties of the topographical surface $8,14,70,71$.

\section{Conclusions}

A mesoporous ceramic was synthesized with the typical characteristics of SBA-15. PLA/SBA-15 composite fibers were produced from the solution by utilizing the air-jet spinning (AJS) method. The morphology of the spun mats was in random fibers morphology, and the AJS allowed to obtain a composite scaffold quickly and in a single step. Due to the textural properties obtained from the SBA-15, the excellent distribution that had along the PLA fibers, and the excellent mechanical properties it presented, indicated that the composite scaffold approaches the cancellous bone ECM morphology. The PLA/SBA-15 composite fiber scaffold improved both the biocompatibility and cell-material properties of the polymer matrix because osteoblasts cells successfully adhered and grew on the scaffolds showing their potential for applications in bone tissue engineering. Therefore, from the in vitro biocompatibility, the PLA/SBA15 fiber composite with $0.05 \mathrm{wt} \%$. showed the best response to bone cells, which open the possibility to carry out more studies as the bioactivity that presented the doped mesoporous ceramic $(0.05 \% \mathrm{wt})$ onto the polymer matrix is determining for the osteoconductivity in bone mineralization model to propose the useful lifetime and future convenient biomedical applications in bone tissue engineering.

\section{Acknowledgments}

The authors want to thanks to the financial support by the DGAPA-UNAM: PAPIIT IT203618 project, and the CONACYT by the particular program of Fondo Sectorial de Investigación para la Educación A1-S-9178 project. OACC want to thank CONACYT scholarship support (No. 463760 with CVU: 622709) for his PhD studies in the Programa de Maestría y Doctorado en Ciencias Médicas, Odontológicas y de la Salud (PMDCMOS), UNAM. Authors want to thank to Raul Reyes Ortíz andAdriana Tejeda Cruz from IIM-UNAM, for their technical assistance.

\section{References}

1. Shadjou N, Hasanzadeh M. Bone tissue engineering using silica-based mesoporous nanobiomaterials:Recent progress. Mater Sci Eng C. 2015;55:401-9.

2. Shruti S, Salinas A, Lusvardi G, Malavasi G, Menabue L, Vallet-Regi M. Mesoporous bioactive scaffolds prepared with cerium-, gallium- and zinc-containing glasses. Acta Biomater. 2013;9(1):4836-44.

3. Hofmann E, Kruger K, Haynl C, Scheibel T, Trebbin M, Forster S. Microfluidic nozzle device for ultrafine fiber solution blow spinning with precise diameter control. Lab Chip. 2018;18(15):2225-34.

4. Chen L, Wang S, Yu Q, Topham PD, Chen C, Wang L. A comprehensive review of electrospinning block copolymers. Soft Matter. 2019;15(12):2490-510.

5. Li G, Zhang T, Li M, Fu N, Fu Y, Ba K, et al. Electrospun fibers for dental and craniofacial applications. Curr Stem Cell Res Ther. 2014;9(3):187-95.

6. Li G, Li P, Chen Q, Mani MP, Jaganathan SK. Enhanced mechanical, thermal and biocompatible nature of dual component electrospun nanocomposite for bone tissue engineering. PeerJ. 2019;7:e6986. http://dx.doi.org/10.7717/peerj.6986.

7. Wubneh A, Tsekoura EK, Ayranci C, Uludag H. Current state of fabrication technologies and materials for bone tissue engineering. Acta Biomater. 2018;80:1-30.

8. Jie Q, Zhang H, Wang Y, Mani MP, Jaganathan SK. Development and blood compatibility assessment of electrospun polyvinyl alcohol blended with metallocene polyethylene and plectranthus amboinicus (PVA/mPE/PA) for bone tissue engineering. Int $\mathrm{J}$ Nanomedicine. 2018;13:2777-88.

9. Suarez-Franco JL, Vazquez-Vazquez FC, Pozos-Guillen A, Montesinos JJ, Alvarez-Fregoso O, Alvarez-Perez MA. Influence of diameter of fiber membrane scaffolds on the biocompatibility of hPDL mesenchymal stromal cells. Dent Mater J. 2018;37(3):465-73.

10. Granados-Hernandez MV, Serrano-Bello J, Montesinos JJ, Alvarez-Gayosso C, Medina-Velazquez LA, Alvarez-Fregoso $\mathrm{O}$, et al. In vitro and in vivo biological characterization of poly(lactic acid) fiber scaffolds synthesized by air jet spinning. J Biomed Mater Res B Appl Biomater. 2018;106(6):2435-46.

11. Mendieta-Barrañon I, Chanes-Cuevas OA, Álvarez-Pérez MA, González-Alva P, Medina LA, Aguilar-Franco M, et al. Physicochemical and tissue response of pla nanofiber scaffolds 
sterilized by different techniques. ODOVTOS-International Journal Dental Science. 2019;21-3:77-88.

12. Alizadeh-Osgouei M, Li Y, Wen C. A comprehensive review of biodegradable synthetic polymer-ceramic composites and their manufacture for biomedical applications. Bioact Mater. 2019;4:22-36.

13. Tajbakhsh S, Hajiali F. A comprehensive study on the fabrication and properties of biocomposites of poly(lactic acid)/ceramics for bone tissue engineering. Mater Sci Eng C. 2017;70(Pt 1):897-912.

14. Jiang H, Mani MP, Jaganathan SK. Multifaceted characterization and in vitro assessment of Polyurethane-Based Electrospun fibrous composite for bone tissue engineering. Int $\mathrm{J}$ Nanomedicine. 2019; 14:8149-59.

15. Hudson SP, Padera RF, Langer R, Kohane DS. The biocompatibility of mesoporous silicates. Biomaterials. 2008;29(30):4045-55.

16. Shadjou N, Hasanzadeh M. Silica-based mesoporous nanobiomaterials as promoter of bone regeneration process. $\mathrm{J}$ Biomed Mater Res A. 2015;103(11):3703-16.

17. Vallet-Regí M, Izquierdo-Barba I, Colilla M. Structure and functionalization of mesoporous bioceramics for bone tissue regeneration and local drug delivery. Philosophical Transactions of the Royal Society A. 2012;370:1400-21.

18. Zhao D, Huo Q, Feng J, Chmelka BF, Stucky GD. Nonionic triblock and star diblock copolymer and oligomeric surfactant syntheses of highly ordered, hydrothermally stable, mesoporous silica structures. J Am Chem Soc. 1998;120(24):6024-36.

19. Wei L, Hu N, Zhang Y. Synthesis of polymer-mesoporous silica nanocomposites. Materials (Basel). 2010;3(7):4066-79.

20. Vallet-Regí M, Colilla M. izquierdo-barba I. Bioactive mesoporous silicas as controlled delivery systems: application in bone tissue regeneration. J Biomed Nanotechnol. 2008;4(1):1-15.

21. Vallet-Regí M, Ruiz-González L, Izquierdo-Barba I, GonzálezCalbet JM. Revisiting silica based ordered mesoporous materials: medical applications. J Mater Chem. 2006;16(1):26-31.

22. Middleton JC, Tipton AJ. Synthetic biodegradable polymers as orthopedic devices. Biomaterials. 2000;21(23):2335-46.

23. Gunatillake PA, Adhikari R. Biodegradable synthetic polymers for tissue engineering. Eur Cell Mater. 2003;5:1-16.

24. Liu X, Ma PX. Polymeric scaffolds for bone tissue engineering. Ann Biomed Eng. 2004;32(3):477-86.

25. Salgado AJ, Coutinho OP, Reis RL. Bone tissue engineering: state of the art and future trends. Macromol Biosci. 2004;4(8):74365.

26. Mistry A, Mikos A. Tissue engineering strategies for bone regeneration. Adv Biochem Eng Biotechnol. 2005;94:1-22.

27. Van Dijkhuizen-Radersma R, Moroni L, van Apeldoorn A, Zhang Z, Grijpma D. Degradable polymers for tissue engineering. In: van Blitterswijk C, Thomsen P, Lindahl A, Hubbell J, Williams DF, Cancedda R, et al., editors. Tissue Engineering. Burlington: Academic Press; 2008. p. 193-221.

28. Van De Velde K, Kiekens P. Biopolymers: overview of several properties and consequences on their applications. Polym Test. 2002;21(4):433-42.

29. Aslankoohi N, Mondal D, Rizkalla A, Mequanint K. Bone repair and regenerative biomaterials: towards recapitulating the microenvironment. Polymers (Basel). 2019;11(9):E1437.

30. Qian Y, Wei P, Jiang P, Li Z, Yan Y, Ji K. Aluminated mesoporous silica as novel high-effective flame retardant in polylactide. Compos Sci Technol. 2013;82:1-7.

31. Song S-W, Hidajat K, Kawi S. Functionalized SBA-15 materials as carriers for controlled drug delivery: influence of surface properties on matrix-drug interactions. Langmuir. 2005;21(21):9568-75.

32. Ortiz-Bustos J, Martín A, Morales V, Sanz R, García-Muñoz RA. Surface-functionalization of mesoporous SBA-15 silica materials for controlled release of methylprednisolone sodium hemisuccinate: Influence of functionality type and strategies of incorporation. Microporous Mesoporous Mater. 2017;240:23645.

33. Stevens WJJ, Lebeau K, Mertens M, Van Tendeloo G, Cool P, Vansant EF. Investigation of the morphology of the mesoporous SBA-16 and SBA-15 materials. J Phys Chem B. 2006;110(18):9183-7

34. Zhao D, Sun J, Li Q, Stucky GD. Morphological control of highly ordered mesoporous silica SBA-15. Chem Mater. 2000;12(2):275-9.

35. Björk EM, Söderlind F, Odén M. Single-pot synthesis of ordered mesoporous silica films with unique controllable morphology. J Colloid Interface Sci. 2014;413:1-7.

36. Zhang F, Yan Y, Yang H, Meng Y, Yu C, Tu B, et al. Understanding effect of wall structure on the hydrothermal stability of mesostructured silica SBA-15. J Phys Chem B. 2005;109(18):8723-32.

37. Badiei A, Haririan I. Jahangir, Ziarani G. Incorporation of ibuprofen into SBA-15; drug loading and release properties. Dynamic Biochemistry. Process Biotechnology and Molecular Biology. 2009;3:48-50.

38. Gascón V, Díaz I, Márquez-Álvarez C, Blanco RM. Mesoporous silicas with tunable morphology for the immobilization of laccase. Molecules (Basel). 2014;19(6):7057-71.

39. Klimova T, Esquivel A, Reyes J, Rubio M, Bokhimi X, Aracil J. Factorial design for the evaluation of the influence of synthesis parameters upon the textural and structural properties of SBA-15 ordered materials. Microporous Mesoporous Mater. 2006;93(13):331-43.

40. Abdal-hay A, Hamdy AS, Lim JH. Facile preparation of titanium dioxide micro/nanofibers and tubular structures by air jet spinning. Ceram Int. 2014;40(Suppl 10 Part A):15403-9.

41. González E, Shepherd LM, Saunders L, Frey MW. Surface functional poly(lactic acid) electrospun nanofibers for biosensor applications. Materials (Basel). 2016;9(1):47.

42. Ishii D, Ying TH, Yamaoka T, Iwata T. Characterization and biocompatibility of biopolyester nanofibers. Materials (Basel). 2009;2(4):1520-46.

43. Gudino J, Medellín-Rodríguez F, Avila-Orta C, Palestino G, Sanchez S. Structure/property relationships of poly(l-lactic acid)/ mesoporous silica nanocomposites. J Polym. 2013;2013:1-10.

44. Manzano M, Lamberti G, Galdi I, Vallet-Regí M. Anti-osteoporotic drug release from ordered mesoporous bioceramics: experiments and modeling. AAPS PharmSciTech. 2011;12(4):1193-9.

45. Nanaki S, Siafaka PI, Zachariadou D, Nerantzaki M, Giliopoulos DJ, Triantafyllidis KS, et al. PLGA/SBA-15 mesoporous silica composite microparticles loaded with paclitaxel for local chemotherapy. Eur J Pharm Sci. 2017;99:32-44.

46. Nieto A, Balas F, Colilla M, Manzano M, Vallet-Regí M. Functionalization degree of SBA-15 as key factor to modulate sodium alendronate dosage. Microporous Mesoporous Mater. 2008;116:4-13.

47. Han X, Wang D, Chen X, Lin H, Qu F. One-pot synthesis of macro-mesoporous bioactive glasses/polylactic acid for bone tissue engineering. Mater Sci Eng C. 2014;43:367-74.

48. Nagarwal RC, Kumar R, Dhanawat M, Pandit JK. Modified PLA nano in situ gel: a potential ophthalmic drug delivery system. Colloids Surf B Biointerfaces. 2011;86(1):28-34.

49. Albayati TM, Salih IK, Alazzawi HF. Synthesis and characterization of a modified surface of SBA- 15 mesoporous silica for a chloramphenicol drug delivery system. Heliyon. 2019;5(10):e02539-02539.

50. Freitas LB O, Bravo IJG, Macedo WAA, Sousa EMB. Mesoporous silica materials functionalized with folic acid: preparation, characterization and release profile study with methotrexate. J Sol-Gel Sci Technol. 2016;77(1):186-204.

51. Ho M-P, Lau K tak, Wang H, Hui D. Improvement on the properties of polylactic acid (PLA) using bamboo charcoal particles. Compos, Part B Eng. 2015;81:14-25. 
52. Kruk M, Jaroniec M, Ko CH, Ryoo R. Characterization of the porous structure of SBA-15. Chem Mater. 2000;12(7):1961-8.

53. Liu X, Wang T, Chow LC, Yang M, Mitchell JW. Effects of inorganic fillers on the thermal and mechanical properties of poly(lactic acid). Int J Polym Sci. 2014;2014:827028.

54. Zhao Y, Qiu Z, Yang W. Effect of functionalization of multiwalled nanotubes on the crystallization and hydrolytic degradation of biodegradable poly(l-lactide). J Phys Chem B. 2008;112(51):16461-8.

55. Kumbar SG, James R, Nukavarapu SP, Laurencin CT. Electrospun nanofiber scaffolds: engineering soft tissues. Biomed Mater. 2008;3(3):034002.

56. Prasadh S, Wong RCW. Unraveling the mechanical strength of biomaterials used as a bone scaffold in oral and maxillofacial defects. Oral Sci Int. 2018;12(5):48-55.

57. He B, Liu C, Wang Z. Mechanical and thermal properties of Electrospun PMIA nanofibers reinforced PLA composites. Mater Sci. 2019;25(2):177-82.

58. Grémare A, Guduric V, Bareille R, Heroguez V, Latour S, L'heureux $\mathrm{N}$, et al. Characterization of printed PLA scaffolds for bone tissue engineering. J Biomed Mater Res A. 2018;106(4):887-94.

59. Jeong H, Rho J, Shin JY, Lee DY, Hwang T, Kim KJ. Mechanical properties and cytotoxicity of PLA/PCL films. Biomed Eng Lett. 2018;8:267-72.

60. Islam MS, Ramli IB, Hasan MR, Islam M, Islam KN, Hasan $\mathrm{M}$, et al. Effect of kenaf and efb fiber hybridization on physical and thermo-mechanical properties of pla biocomposites. Fibers Polym. 2017;18(1):116-21.

61. Fu Q, Jia W, Lau GY, Tomsia AP. Strength, toughness, and reliability of a porous glass/biopolymer composite scaffold. J Biomed Mater Res B Appl Biomater. 2018;106(3):1209-17.

62. Armentano I, Dottori M, Fortunati E, Mattioli S, Kenny JM. Biodegradable polymer matrix nanocomposites for tissue engineering: A review. Polym Degrad Stabil. 2010;95(11):2126-46.
63. Chen H, Truckenmüller R, Van Blitterswijk C, Moroni L. Fabrication of nanofibrous scaffolds for tissue engineering applications. In: Gaharwar AK, Sant S, Hancock MJ, Hacking AA. Nanomaterials in tissue engineering fabrication and applications. Amsterdam: Woodhead Publishing; 2013. p. 158-83.

64. Kroeze RJ, Helder MN, Govaert LE, Smit TH. Biodegradable polymers in bone tissue engineering. Materials (Basel). 2009;2(3):833-56.

65. Zimmermann EA, Ritchie RO. Bone as a structural material. Adv Healthc Mater. 2015;4(9):1287-304.

66. Pelipenko J, Kocbek P, Govedarica B, Rošic R, Baumgartner $\mathrm{S}$, Kristl J. The topography of electrospun nanofibers and its impact on the growth and mobility of keratinocytes. Eur J Pharm Biopharm. 2013;84(2):401-11.

67. Montjovent M-O, Mark S, Mathieu L, Scaletta C, Scherberich A, Delabarde C, et al. Human fetal bone cells associated with ceramic reinforced PLA scaffolds for tissue engineering. Bone. 2008;42(3):554-64.

68. Apalangya VA, Rangari VK, Tiimob BJ, Jeelani S, Samuel T. Eggshell based nano-engineered hydroxyapatite and poly(lactic) acid electrospun fibers as potential tissue scaffold. Int J Biomater. 2019;2019:6762575.

69. Anselme K. Osteoblast adhesion on biomaterials. Biomaterials. 2000;21(7):667-81.

70. Hoveizi E, Nabiuni M, Parivar K, Rajabi-Zeleti S, Tavakol S. Functionalization and surface modification of electrospun polylactic acid scaffold for tissue engineering. Cell Biol Int. 2014;38(1):41-9.

71. Zhang R, Elkhooly TA, Huang Q, Liu X, Yang X, Yan H, et al. Effects of the hierarchical macro/mesoporous structure on the osteoblast-like cell response. J Biomed Mater Res A. 2018;106(7):1896-902. 